\title{
O odbiorze dzieła literackiego
}

\begin{abstract}
Wachowski Jacek, O odbiorze dzieła literackiego [On the reception of a literary work]. "Przestrzenie Teorii" 28. Poznań 2017, Adam Mickiewicz University Press, pp. 95-107. ISSN 1644-6763. DOI 10.14746/pt.2017.28.3.
\end{abstract}

The article is an attempt to answer the question: what happens to a literary work - understood as Ingarden's purely intentional objects - from the recipient's perspective? And also: how do the images of objects arise in the minds of the audience and what are their properties? Transferring purely intentional objects to the recipient's perspective changes their status: mental images of objects are subject to numerous fluctuations (based on emotions and cognitive processes). In this way they are transformed into forms that are non-permanent reflections of objects belonging to a literary work. Referring to Ingarden's terminology, one might say that they become purely intentional reflections (or reflections of purely intentional objects). The article is an attempt to characterize and stratify them.

KEYWORDS: reception of literary works, intentional acts, Ingarden, literary theory, philosophy

\section{1.}

Ustalenia Edmunda Husserla - przedstawione w drugiej teorii intencjonalności ${ }^{1}$ - miały ogromny wpływ na całą nowoczesną humanistykę (w tym także na literaturoznawstwo) ${ }^{2}$. Zasługa niemieckiego filozofa stało się bowiem odkrycie, iż osiami aktów poznawczych są noezy i noematy. Pierwsze odnoszą się do takiego sposobu rozumienia świata (przedmiotów, procesów i zjawisk), który wypływa z immanencji podmiotu (i przez nią jest ukształtowany). O noezach można zatem powiedzieć, że są spełnieniem mentalnej intencji podmiotu o konkretnej treści (wyrazem poznawczego potencjału, skierowanego na określony cel). Noematy z kolei to bezpośrednie przyczyny noez $^{3}$ - przywoływane w myślach obrazy przedmiotów, zjawisk lub proce-

${ }^{1}$ Zob. E. Husserl, Vorlesungen über Bedeutungslehre. Sommersemester 1908, Husserliana XXVI, hrsg. von U. Panzer, Dordrecht 1986, s. 35.

${ }^{2} \mathrm{Na}$ temat historii intencjonalności w dziejach myśli europejskiej zob. m.in. J. Krokos, Odstanianie intencjonalności, Warszawa 2013, < http://www.liberilibri.pl/krokos>.

${ }^{3}$ Por. A. Chrudzimski, Teoria intencjonalności Romana Ingardena, „Edukacja Filozoficzna” 1998, nr 25, s. 250. Husserl uważał, że noematami mogą być zarówno przedmioty w rozumieniu Meinongowskim, a więc przedmioty, które faktycznie - fizykalnie istnieją w świecie albo muszą w nim zachodzić (co oznacza, że stają się korelatem intencji, ich celem, dzięki któremu intencja staje się trafna - prawdziwa) - jak też takie, które stanowią rodzaj zapośredniczenia w świecie fizykalnym, który sam w sobie nie jest rzecz jasna celem intencji, ale jest jej (intencji) korelatem. Korelatem - dodajmy - który nie ma podłoża logicznego, ale raczej quasi-przyczynowe, to znaczy takie, które powstaje na mocy skojarzeń poznawczych 
sów. Są one korelatami noez, które - jak mówi Husserl - „stają nam przed oczyma" w trakcie aktów poznawczych ${ }^{4}$.

Niezależnie od wysiłków Husserla - zmierzających do opisania noematów - ich status może się wydać nie dość wyrazisty. Co więcej, noematy moga wywoływać wrażenie, iż stanowią część noez. W istocie różnią się od nich dość znacznie. Po pierwsze dlatego, że gdy podmiot chce pomyśleć o przedmiocie swojego poznania, to musi najpierw ów przedmiot przywołać w myślach i dopiero na tej podstawie stworzyć jego rozumienie. Kolejność ta jest niezmienna ${ }^{5}$. Nie można bowiem zrozumieć przedmiotu poznania, zanim nie przywoła się go w myślach, to znaczy zanim nie odpowie się na pytanie: co jest przedmiotem poznawczego namysłu? Po drugie, nie wszystkie przedmioty, które podmiot przywołuje w myślach, musi rozumieć. Są takie, które wymykają się jego poznaniu lub czynią rozumienie niekoniecznym. Dotyczy to w szczególności przedmiotów, których nie zna lub wcześniej nie widział i nie potrafi nic powiedzieć o ich funkcjach oraz możliwym zastosowaniu. Niezależnie jednak od tego, iż nie wie, czym sa, potrafi stworzyć ich mentalne obrazy ${ }^{6}$.

Niejasny (nieokreślony) status noematów spowodował, że to właśnie one (a nie noezy) stały się głównym obszarem zainteresowania fenomenologów. Z tych samych powodów znalazły się w centrum rozważań Romana Ingardena. Autor Sporu o istnienie świata ${ }^{7}$ znacząco zmienił jednak sposób

podmiotu, które nie znajdująca - niejednokrotnie - oparcia w zasadach indukcyjno-dedukcyjnych.

${ }^{4} \mathrm{Tu}$ jednak powstają nowe wątpliwości: co to znaczy, że przedmioty fizykalne sa korelatem intencjonalnym i w jaki sposób taka korelacja zachodzi (czy przebiega tak samo w przypadku wszystkich innych przedmiotów)? Czy jest jakaś różnica między przedmiotami, które posiadają swoje korelaty? Czy korelaty wpływają (a jeśli tak, to w jaki sposób) na powstawanie przedmiotów?

${ }^{5} \mathrm{~W}$ przypadku większości aktów poznawczych można odnieść wrażenie, iż są jednorodne - że noezy i noematy pojawiają się nie tylko łącznie, ale też są ze sobą „zrośnięte”. To subiektywne wrażenie (powstające wyłącznie w wyniku braku wystarczającego namysłu nad przebiegiem aktów poznawczych) nie zmienia jednak faktu, że mają one postać dwuetapowa.

${ }^{6}$ Obserwacja Heideggera - mówiącego, że jestem, zanim zdążę pomyśleć (to znaczy jestem niezależnie od tego, że myślę) - symbolicznie przenosi się na poznawanie przedmiotów czysto intencjonalnych. Oto bowiem podmiot może powiedzieć, że przywoływane przedmioty intencjonalne sa (istnieja) w jego myślach niezależnie od tego, czy obdarza je rozumieniem. Ich byt jest bowiem czymś innym niż proces poznawczy, który je obejmuje (który się do nich odnosi). Innymi słowy, podmiot może przywołać w myślach przedmiot nie po to, żeby obdarzać go rozumieniem, ale żeby pozostawać na poziomie jego ogólnego wyobrażenia. Por. M. Heidegger, Kant a problem metafizyki, tłum. B. Baran, Warszawa 1989, s. 233.

${ }^{7}$ R. Ingarden, Spór o istnienie świata. Kraków 1947. „Sporem o istnienie świata nazywa Roman Ingarden kontrowersję pomiędzy stanowiskiem idealistycznym a realistycznym w filozofii. W szczególności chodzi o ocenę prawomocności stanowiska transcendentalnego idealizmu, 
ich rozumienia ${ }^{8}$. W ujęciu Ingardena noematy były bowiem nie tylko celem intencji i jej zapośredniczeniem, ale przede wszystkim wytworem aktu świadomości ${ }^{9}$. Ingardenowiskie rozumienie noematów - nawet jeśli nawiązywało do koncepcji filozofów, którzy dopuszczali, iż podmiot może poznawać idee będące przedmiotami jego myśli (to znaczy wszystkimi wytworami myśli, niezależnie od poziomu ich realności) ${ }^{10}$ - szło jednak znacznie dalej. Opierało się bowiem na przekonaniu, iż noematy jako wytwory świadomości, znajdują się w wyłącznej dyspozycji podmiotu.

Koncepcja przyznająca odbiorcy prawo do wytwarzania noematów domagała się jednak głębszego rozpoznania oraz nowych terminologicznych propozycji. Zostały one sformułowane w związku z refleksją na temat sposobu istnienia dzieła literackiego. Tu też dokonał Ingarden najważniejszego zwrotu w fenomenologicznym myśleniu. Aby wydobyć szczególne właściwości dzieła literackiego (które było dlań przykładem przedmiotu wyłącznie intencjonalnego) zastapił Husserlowskie noematy przedmiota mi czysto intencjonalnymi ${ }^{11}$.

Ingardenowi nie chodziło jednak wyłącznie o nową terminologię. Przedmioty czysto intencjonalne miały bowiem zasadniczo odmienny status od

w sensie ustalonym przez Edmunda Husserla. Idealizm jest przy tym interpretowany przez Ingardena jako teza o stosunku bytowym pomiędzy światem i (czysta) świadomościa, teza, którą daje się wyprecyzować w postaci zespołu szczegółowych twierdzeń o sposobie istnienia świata i jego składników. Pochodzenie zagadnienia jest kartezjańskie i wiąże się z odkryciem przez Kartezjusza oraz jego następców problematyki wynikającej z zasadniczej możliwości podawania w wątpliwość wszelkich wyników doświadczenia zmysłowego, a więc i wątpienia w istnienie realne przedmiotów tego doświadczenia”. Zob. J. Hartman, Spór o istnienie świata, [w:] Stownik pojęć filozoficznych Romana Ingardena, red. A. Nowak, L. Sosnowski. Kraków 2001, s. 250.

${ }^{8} \mathrm{O}$ bezsprzecznym istnieniu świata przesądzała - zdaniem Ingardena - jego niezależność od woli podmiotu i podejmowanych przezeń aktów świadomości. Procesy i zjawiska oraz przedmioty należące do świata, niewymagające akceptacji podmiotu (a niejednokrotnie dokonujące się wbrew jego intencjom) świadczą o tym, iż są częścią jakiejś transcendentnej rzeczywistości, która istnieje niezależnie od podmiotu. Ze względu na to, że zachodzą one bez woli podmiotu, wyprowadzić można wniosek, że muszą istnieć realnie - to znaczy, że nie są efektem intencji podmiotu.

${ }^{9}$ Zob. A. Chrudzimski, dz. cyt., s. 249-250.

${ }^{10}$ Tamże, s. 120.

${ }^{11}$ Szczególnie ważne okazało się to, że Ingarden opisał przedmioty czysto intencjonalne za pomoca czterowarstwowej i dwuwymiarowej struktury. Oznaczało to, że można o nich pomyśleć poprzez brzmienia i sensy, do których brzmienia się odnoszą (obiekty i postaci, o których literatura opowiada), a dalej poprzez cały świat przedstawiony, w którym owe obiekty i postaci występuja, oraz poprzez wyobrażenia, które jako odbiorcy mamy na ich temat lub/i które możemy sobie wyobrazić. Dzięki temu dzieło literackie może być przedmiotem licznych konkretyzacji, które mogą odzwierciedlać relacje między dziełem a atmosferą literacką epoki oraz stosunek czytelnika do dzieła. Zob. R. Ingarden, Studia z estetyki, t. 1, Warszawa 1956, s. 242 oraz tegoż, O dziele literackim, Warszawa 1960, s. 431-432. 
noematów - odnosiły się do aktualnych aktów wytwarzanych przez podmiot. Co więcej, jako wytwory immanencji nie musiały pozostawać w żadnych (weryfikowalnych) relacjach ze światem zewnętrznym (fizykalnym). Uzasadnieniu takiego przekonania służyć miało wyznaczenie dwóch szeregów, przysługujacych im własności. Pierwszy dotyczył sposobu powstawania przedmiotów - a więc tego, że są wytwarzane przez podmiot i stanowią efekt jego mentalnego wysiłku. Drugi odnosił się do ich zawartości, a więc do tego, że mają budowę warstwową ${ }^{12}$.

Ujęcie takie, oprócz innych zalet miało także i tę, że pozwalało na odejście od trudnego do rozstrzygnięcia sporu, powracającego w dyskusjach fenomenologów od czasów Bolzano i Meinonga ${ }^{13}$ (sprowadzającego się do pytania: w jakich relacjach noematy pozostają do świata fizykalnego?). O Ingardenowskich przedmiotach można było powiedzieć, że są przedmiotami intencji jako takiej, a nie przedmiotami jako takimi - że mogą odnosić się do rzeczywistości fizykalnej (ale nie jest to warunkiem ich egzystencji). Co jednak najważniejsze, że są bytami osobnymi i niezależnymi od świata fizykalnego - i że stanowią wytwór intencji podmiotu, odzwierciedlający sferę jego immanencji.

Status przedmiotów czysto intencjonalnych prowokował też do postawienia pytań o charakter ich społecznego obiegu - w szczególności o to, czy należą one wyłącznie do dzieła, czy może również do czytelników. Zaskakująco cenne spostrzeżenia zawdzięczamy w tym względzie Stanisławowi Lemowi. Uwagi przedstawione w Filozofii przypadku skłaniały do wniosku, iż Ingardenowskie przedmioty mogą być wytwarzane w dwóch obiegach: autorskim (stanowiącym wytwór immanencji autora) i czytelniczym (który powstaje na styku dzieła i wyobraźni odbiorcy) ${ }^{14}$. Niezależnie więc od tego, że należą do utworu literackiego, są także własnością odbiorców, ponieważ to w ich przestrzeni poznawczej są dekodowane (obecne są w ich myślach i w nich podlegają licznym przekształceniom, sa pamięta-

\footnotetext{
${ }^{12}$ Por. A. Chrudzimski, dz. cyt., s. 250.

${ }^{13}$ A. Meinong, „Über Gegenstandstheorie”, in Gesamtausgabe, Graz 1971, s. 481-535.

${ }^{14}$ Osobną kategorię stanowia przedmioty czysto intencjonalne, które wytwarzają inne przedmioty czysto intencjonalne. Przykładów takich dostarczają tu dobrze opisane relacje międzytekstowe, wyrażające się w bezpośrednich lub pośrednich nawiązaniach tekstu do tekstu. Związki takie najpełniej opisał Gerard Genette w swojej książce Palimsestes. La literature au second degre, Paris 1982 (zainspirowanej słynnym dziełem Julii Kristevej, Semiotique. Recherches pour une semanalise, Paris 1969). Mowa tu oczywiście o dziełach literackich, a nie o dziełach z zakresu literaturoznawstwa (lub pokrewnych dyscyplin). Te ostatnie - naukowe - tworzą inną kategorię wypowiedzi. Więcej na ten temat zob. m.in. Ł. Wróbel, Intencjonalność i referencja. Ku fenomenologii form gatunkowych. „Teka Komisji Polsko-Ukraińskich Związków Kulturowych”, Lublin 2009, z. 4, s. 44-45.
} 
ne i wspominane - ale również zapominane $)^{15}$. W ten sposób odsłaniaja swą podwójną egzystencję. Pierwsza - jest niezależna od woli czytelnika i należy do dzieła. Druga natomiast - należy do odbiorców dzieła i jest przez nich wytwarzana.

\section{2.}

Przeniesienie przedmiotów czysto intencjonalnych do perspektywy odbiorczej jest jednak procesem złożonym - zmienia ich status, staje się wyzwaniem poznawczym i terminologicznym. Przede wszystkim jednak uświadamia, że mentalne obrazy przedmiotów podlegają licznym fluktuacjom (których podłożem mogą być zarówno emocje, jak też procesy kognitywne). Wreszcie, że są one trudno weryfikowalne, a więc, że nie podlegają żadnemu zobiektywizowanemu systemowi ocen, który pozwalałby na ich prosta i jednoznaczną deskrypcję. Można zatem powiedzieć, że przedmioty czysto intencjonalne przeniesione do przestrzeni odbiorczej traca swoje dawne właściwości i przekształcają się w formy, które są nietrwałymi odbiciami przedmiotów należących do dzieła literackiego.

Nawiązując do Ingardenowskiej terminologii, należałoby o nich powiedzieć, że stają się r efleks a mi czysto intencjonalnymi (albo r eflek s a mi przedmiotów czysto intencjonalnych). Aby zrozumieć, jak refleksy powstaja (i jak są skonstruowane), przypomnieć trzeba najpierw, że dzieło literackie ma charakter linearny i jest delimitowane (co oznacza, że składa się z następujących po sobie sekwencji odpowiednio umotywowanych, a także, że ma swój początek i koniec). Obie właściwości pozwalają na prześledzenie procedur myślowych, związanych z odbiorem utworu literackiego i umożliwiaja zrozumienie mechanizmów, w oparciu o które owe procedury powstaja.

Zaczaćc wypada od tego, że pomyślenie o całym dziele jest niemożliwe. Można je oczywiście zacytować, ale to nie to samo, co pomyśleć o jego przebiegu ${ }^{16}$. Myślenie o utworze literackim może mieć postać nielinearną i nie musi być zgodne z jego strukturą kompozycyjna, fabularną i językowa. Opiera się zawsze na selekcji - na wyborze, dotyczącym konkretnej sceny,

${ }^{15}$ Przekonanie Lema, iż stereometryczna budowa dzieła literackiego nie jest cechą genotypu, lecz należy do porządku lektury, stało się podstawą twierdzenia, że „nie dzieło jest warstwowym utworem hierarchicznym, ale proces jego odbioru tak się przedstawia”. Zob. S. Lem, Filozofia przypadku. Literatura w świetle empirii, Kraków 1968, s. 327.

${ }^{16}$ Podczas gdy cytowanie jest odtworzeniem linearnej struktury dzieła, pomyślenie o nim oznacza wytworzenie jakiejś jego reprezentacji. Większość czytelników nie uczy się dzieł literackich na pamięć, a nawet nie pamięta dokładnie ich fabularnego przebiegu, ale nie przeszkadza im to o dziełach pomyśleć. 
postaci, zdarzenia lub sekwencji zdarzeń (które „stają nam przed oczyma”). Może też przybrać postać refleksji ogólnych, obejmujących całe dzieło - przywołujących jego klimat lub symboliczne idee.

Pomyślenie o dziele ma również związek z pamięcią. Wiąże się bowiem z pytaniem: dlaczego zapamiętuję to, co zapamiętuję? Czy zapamiętywane obrazy mają charakter statyczny, czy dynamiczny? Czy zawsze zapamiętuję jakąś część dzieła? Od czego zależy, że zapamiętuję całość (ogólne wrażenie, ideę, przesłanie stanowiące wyraz ogólniejszych aspiracji poznawczych)? Wreszcie: czy zapamiętuję dzieło czy raczej swoje myśli na jego temat?

Pytania te prowadzą do wniosku, że refleksy czysto intencjonalne (podobnie jak Ingardenowskie przedmioty), powstają w dwóch fazach. W pierwszej następuje ich selekcja. Rządzi nią subiektywne przekonanie odbiorcy, iż właśnie te, a nie inne przedmioty stanowią najlepszą reprezentację dzieła literackiego i umożliwiają dotarcie do jego sensu. Wydaje się, że działają tu zasady zbliżone do tych, które znamy z percepcji wzrokowej. Patrząc na przedmiot - jak mówi Rudolf Arnheim - zawsze widzimy jakiś jego fragment. Obrazy przechowywane w pamięci składają się z cech zapamiętanych, które moga (ale nie musza) być najważniejszymi właściwościami owych przedmiotów ${ }^{17}$.

Refleksy czysto intencjonalne - opierając się na grze między tym, co jawne i ukryte (pozostające w sferze świadomości czytelnika i domyślne) wywołują naturalne skojarzenia z dobrze znaną konstrukcją synekdochy. $\mathrm{Z}$ jednej strony są wyborem części reprezentującej całość (pars pro toto) ${ }^{18}$, z drugiej pozwalają na opisanie całości reprezentującej ukryte części (totum pro parte). Podczas gdy synekdocha części pozwala na wyznaczenie pojedynczych i symbolicznych sensów, synekdocha całości wyraża ogólną ideę dzieła, pozwalającą objąć sensy poszczególne.

Wydaje się jednocześnie, że konstrukcja synekdochy dobrze odzwierciedla strukturę aktów poznawczych, stanowiących (również) przedmiot badań kognitywistycznych i neurofizjologicznych. Sposób kojarzenia przedmiotów, przywoływania ich w myślach i przechowywania w pamięci uświadamia, że dynamika naszego myślenia przyjmuje - pod wieloma względami - postać synekdochiczna. Składa się bowiem z reprezentacji (obejmujących przedmioty, procesy i zjawiska), które mają postać skumulowanych sensów -

${ }^{17}$ Zob. R. Arnheim, Myślenie wzrokowe, tłum. M. Przylipiak, Gdańsk 2011, s. 128.

${ }^{18}$ Wybór części wypływa każdorazowo z indywidualnych cech podmiotu, a więc z tego, co Husserl i Ingarden określali mianem immanencji podmiotu. Możemy zatem powiedzieć, że przywoływaniem przedmiotu czysto intencjonalnego rządzi synekdocha, ale sam wybór przedmiotu uzależniony jest od właściwości samego podmiotu. Prowadzi to do wniosku, że ilość możliwych przedmiotów czysto intencjonalnych reprezentujących dzieło literackie jest tak duża, jak liczba odbiorców. 
ośrodków znaczeniowych - zdolnych do przekształcania się w dłuższe ciagi semantyczne. W ten sposób mogą być one zapamiętywane i przywoływane w dogodnych dla użytkownika okolicznościach ${ }^{19}$.

Konstrukcja synekdochy pozwala jednak wyłącznie na częściową charakterystykę refleksów. Umożliwia opisanie mechanizmów, mówiących o tym, ,jak" przedmioty należące do dzieła literackiego sa przywoływane (to znaczy: ,jak stają się refleksami czysto intencjonalnymi”). Nie odnosi się jednak do tego, „co” jest ich materią. Pytania te wprowadzaja bowiem do fazy drugiej. W jej obrębie można wyznaczyć trzy warianty. Pierwszy polega na tym, że refleksy sa odbiciem pojęć ogólnych lub idei (i przybieraja postać synekdochiczno-ideowa). Drugi, w którym rolę odniesień pełnią konkretne obrazy - statyczne, zatrzymane w kadrze (przyjmują one postać synekdochiczno-przedmiotowa). Trzeci, polegający na tym, że przywołane sekwencje zdarzeń, mają formę ruchowa, dynamiczną (dzięki czemu refleksy przyjmuja postać synekdochiczno-performatywna).

\section{3.}

Wydaje się, że refleksy czysto intencjonalne mogą mieć pewien związek $\mathrm{z}$ kryteriami genologicznymi. Ich materia sa bowiem narracje, utrwalone w obrębie poetyk poszczególnych gatunków (to w ich strukturze dokonuje się wybór części reprezentujących całość - albo odwrotnie). Argumentem na rzecz takiego poglądu jest także i to, że aby pomyśleć o fabule, nie trzeba przywoływać jej w całości. Można pomyśleć o jej fragmencie, który z punktu widzenia podmiotu wydaje się wystarczająco reprezentatywny.

Najlepiej widać to na przykładzie dramatu, dla którego składnik performatywny (dotyczący scenicznego ruchu, gestu i proksemiki) stanowi konieczny warunek zrozumienia tekstu. Aby się o tym przekonać, warto przypomnieć dylematy filologów i teatrologów dotyczące utworów najdawniejszych. Pytanie: co robi Klitajmestra w pierwszej scenie Agamemnona? ma kluczowe znaczenie dla interpretacji tragedii Ajschylosa. Niezależnie od tego, że większość badaczy przychyla się do opinii, iż królowa wchodzi na scenę dopiero przy drugiej wypowiedzi chóru, która jest skierowana właśnie do niej (czyli w okolicy 257. wiersza), to są i tacy, którzy twierdza, że może być ona obecna na scenie od początku albo też, że wchodzi i schodzi ze sceny (jest więc obecna od wiersza 82. do 103., a następnie wraca dopiero

${ }^{19}$ Zob. m.in. D.E. Rumelhart, The architecture of mind. A connectionist approach, [w:] Foundation of Cognitive Science, red. M.J. Posner, Boston 1993, s. 133-159; a także: A. Damasio, Jak umyst zyskat jaźń. Konstruowanie świadomego mózgu, tłum. N. Radomski, Poznań 2011; tenże, Bład Kartezjusza. Emocje, rozum i ludzki mózg, tłum. M. Karpiński, Poznań 2011. 
po wierszu 257. ${ }^{20}$. Co miałaby jednak robić, nie schodząc ze sceny? Odprawiać dromena? A jeśli pojawia się później, to czy jej wejściu nie powinny towarzyszyć inne czynności? Jakie?

Spór dotyczący Klitajmestry pozwala na sformułowanie dwóch uwag. Po pierwsze, że zrozumienie początkowej sceny Agamemnona (a może i czegoś więcej) zależy od tego, która z wersji działań Klitajmestry uznamy za właściwa. Po drugie, że przyjęcie określonej hipotezy ruchu królowej staje się niejako automatycznym wyposażeniem wizerunku postaci. O dramatis personae myślimy bowiem przez działania, czyny. Postaci nie tylko mówia, ale także wykonują czynności, które określają ich byt w stopniu nie mniejszym niż słowa.

Czy taki tryb lektury jest jednak wyłącznie domeną dramatu? Z podobnymi właściwościami mamy również do czynienia w utworach prozatorskich. O Czarodziejskiej górze bez trudu można pomyśleć w sposób „dramatyczny” na przykład przywodząc na pamięć żywiołowy agon Settembriniego z Naphtą (co nie zmienia faktu, że o tej samej scenie można pomyśleć poprzez pryzmat filozoficznego sporu odnoszącego się do fundamentalnych kwestii ontycznych). Nie mniej tajemnicza niż Klitajmestra może się wydać Madame Chauchaut wchodząca do restauracji (i nawet jeśli jej wejście nie niesie ze sobą tylu zagadek, co wejście Klitajmestry, to może pozostawać ważnym składnikiem rozumienia tekstu). Sposób lektury utworów prozatorskich nie musi - jak widać - różnić się od dramatycznych. Opozycje gatunkowe zanikają bowiem w planie myślenia o dziełach. Sa kryterium ważnym, ale nie decydującym o sposobie powstawania refleksów.

$\mathrm{Z}$ nieco inna sytuacja mamy pod tym względem do czynienia w liryce. Kiedy czytelnik myśli o słońcu „na tęczujących nitkach niewidzialnej łodygi" - ze słynnego wiersza Tadeusza Peipera Kwiat ulicy ${ }^{21}$ - to musi wytworzyć refleks intencjonalny, nie tylko w oparciu o świat przedstawiony w utworze, ale także o własne doświadczenie. Aby zrozumieć, że „tęczująca nitka" oznacza wielobarwną wibrację kolorów, które czynia łodygę niewidzialna, przywołać musi złudzenie wzrokowe - znane nie tylko czytelnikom poezji Peipera - które powstaje wtedy, gdy patrzymy na kwiaty w blasku oślepiającego słońca. Wrażenie wibracji barw i zanikania przedmiotu należy w ten sposób zarówno do tekstu, jak też do doświadczeń czytelnika.

$\mathrm{Z}$ podobną sytuacja mamy do czynienia $\mathrm{w}$ wierszu otwierającym debiutancki tomik Wincentego Różańskiego, rozpoczynający się od słów: „kry lodowe płynęły na wznak, jakby się ktoś narodził" ${ }^{22}$. Nie chodzi tu wyłącznie o wyobrażenie ruchu, choć takie przypuszczenie wydaje się dominują-

${ }^{20}$ Zob. J. Axer, Filolog w teatrze, Warszawa 1991, s. 23.

${ }^{21}$ Zob. T. Peiper, Żywe linie, Kraków 1924, s. 9.

${ }^{22}$ Zob. W. Różański, Dziecko idace jak włócznia śpiewało, Poznań 1970, s. 5. 
ce, ale raczej o to, iż „kry lodowe” mogą płynąć (leżeć) „na wznak”, a także, że pozycja ta ma jakiś związek z narodzinami dziecka. Znaczenia, które powstają w tekście, odnoszą się do doświadczeń somatycznych czytelnika i uruchamiają taką perspektywę poznawcza, która łączy rozumienie tekstu z wymiarem ponadtekstowym, egzystencjalnym, somatycznym.

Przykłady te uświadamiaja, że to nie kryteria gatunkowe odgrywają decydująca rolę w powstawaniu refleksów czysto intencjonalnych, ale zawarte w nich konstrukcje narracyjne ${ }^{23}$. Można bowiem powiedzieć, że wszędzie tam, gdzie mamy do czynienia z przewaga fabuł nad akcja, powstają warunki do tworzenia się refleksów o komponencie przedmiotowym (statycznym), natomiast tam, gdzie górę bierze akcja, dominuja refleksy performatywne (dynamiczne). Skłonność ta wynika z tego, że fabuły są zamkniętymi i zwartymi konstrukcjami, których przywołanie nie wymaga od odbiorcy żadnych dodatkowych wysiłków. Wyraziste fabuły przenoszą refleksy w stronę idei, ogólnych kategorii poznawczych, a także konkretnych przedmiotów, które mogą być ich symbolami. Z przeciwną sytuacją mamy do czynienia w dziełach, w których akcja dominuje nad fabuła. Skłaniaja one odbiorców do fabularyzacji akcji do tworzenia ekwiwalentów fabuł (to znaczy konstruowania relacji przyczynowo-skutkowych, między niepowiazanymi ze sobą ogniwami). Fabularyzacja akcji może przyjmować zarówno postać interpretacji, które wchodzą do społecznego obiegu, jak też takich, które mają postać hermetyczna, dostosowaną do potrzeb odbiorcy.

Powiedzieć trzeba jednak wyraźnie, że preferencje dotyczące konstrukcji narracyjnych poszukują dopełnień w warstwowej (stereometrycznej, jak mówi Lem) budowie literackich dzieł. Powód wydaje się dość oczywisty: naturalnymi składnikami fabuł i akcji są przedmioty przedstawione w utworach literackich i relacje, które między nimi występuja, a także znaczenia przypisywane owym przedmiotom i ich wyglądy uschematyzowane. Oznacza to, że dopiero połączenie konstrukcji narracyjnych z wybranymi fragmentami dzieł, tworzy warunki do powstawania refleksów.

${ }^{23}$ Refleksy czysto intencjonalne mają pewien związek z organizacją mowy w dziele literackim. Wydaje się, że mowa niezależna (w pewnych okolicznościach pozornie zależna) tworzy warunki dla powstawania refleksów o cechach performatywnych i przedmiotowych. Wynika to z tego, że w mowę niezależną (w mniejszym stopniu w pozornie zależna) wpisane są informacje na temat ruchu postaci, ich działań i czynów. W miarę przechodzenia do mowy zależnej powstają warunki do przedstawiania ogólnych pojęć, kategorii i idei, a także obyczajów i wydarzeń historycznych wpisanych w dłuższą perspektywę historyczno-społeczną. Wydaje się jednak, że dominująca rolę w powstawaniu refleksów odgrywają kategorie narracyjne (opierające się na fabułach i akcji). Dzieje się tak dlatego, że czytelnicy znacznie łatwiej zapamiętują sposób prowadzenia narracji, niż jej językową strukturę. Zapamiętują raczej następujące po sobie wydarzenia, niż sposób przedstawienia ich w aktach mowy. 
O refleksach czysto intencjonalnych można zatem powiedzieć, iż powstają na przecięciu dwóch porządków: konstrukcji narracyjnych (opierających się na fabułach i akcjach) oraz struktur dzieła (ujawniajacych się w budowie warstwowej). Relacje, które zachodzą między nimi, można przedstawić następująco:

Tabela 1. Sposób powstawania refleksów czysto intencjonalnych

\begin{tabular}{|l|l|l|l|l|}
\hline $\begin{array}{l}\text { Narracja/ } \\
\text { struktura }\end{array}$ & \multicolumn{1}{|c|}{$\begin{array}{c}\text { Warstwa } \\
\text { brzmieniowa }\end{array}$} & \multicolumn{1}{|c|}{$\begin{array}{c}\text { Warstwa } \\
\text { znaczeniowa }\end{array}$} & $\begin{array}{c}\text { Warstwa } \\
\text { przedmiotów } \\
\text { przedstawionych }\end{array}$ & $\begin{array}{l}\text { Warstwa wygla- } \\
\text { dów uschematy- } \\
\text { zowanych }\end{array}$ \\
\hline Fabuła & brak refleksów & $\begin{array}{l}\text { refleksy } \\
\text { synekdochiczno- } \\
\text {-ideowe }\end{array}$ & $\begin{array}{l}\text { refleksy } \\
\text { synekdochiczno- } \\
\text {-przedmiotowe }\end{array}$ & $\begin{array}{l}\text { refleksy } \\
\text { synekdochiczno- } \\
\text {-przedmiotowe }\end{array}$ \\
\hline Akcja & $\begin{array}{l}\text { refleksy } \\
\text { synekdochiczno- } \\
\text {-performatywne }\end{array}$ & $\begin{array}{l}\text { refleksy } \\
\text { synekdochiczno- } \\
\text {-performatywne }\end{array}$ & $\begin{array}{l}\text { refleksy } \\
\text { synekdochiczno- } \\
\text {-przedmiotowe } \\
\text { i synekdochiczno- } \\
\text {-performatywne }\end{array}$ & $\begin{array}{l}\text { refleksy } \\
\text { synekdochiczno- } \\
\text {-przedmiotowe } \\
\text { i synekdochiczno- } \\
\text {-performatywne }\end{array}$ \\
\hline
\end{tabular}

Wydaje się, że najmniej produktywne (dla powstawania refleksów) jest połączenie narracji fabularnych i warstwy brzmieniowej. Jeśli brzmienia są niezrozumiałe, to nie wchodzą z fabułą w żadne relacje. Można się o tym przekonać, słuchając dźwięków należących do języka, którego nie znamy albo eksperymentów spod znaku poezji lingwistycznej czy dadaistycznej - na przykład takich jak Ur sonate Kurta Schwittersa, składającej się ze zbitek spółgłoskowych, tworzących ciagi onomatopeiczne, oderwane od swoich pól znaczeniowych (lub powiązane z nimi czysto intuicyjnie i zrywające tym samym symboliczne relacje między brzmieniami i znaczeniami, właściwe dla komunikacji językowej).

$\mathrm{Z}$ inną sytuacją mamy do czynienia tam, gdzie czytelnik nie chce albo nie musi rekonstruować fabuły, gdzie uwolniony jest od konieczności śledzenia przedmiotów przedstawionych w dziele literackim i w naturalny sposób skłania się ku myśleniu na temat ogólnych ideowych założeń utworu. W ten sposób powstają refleksy opierające się na synekdochach całości, które swą podstawą czynią ogólny sens albo problem o charakterze ponadprzedmiotowym. Z jeszcze inną sytuacją mamy do czynienia wtedy, gdy znaczenia nie są wpisane w fabułę, ale wynikaja z akcji. Aby je zrekonstruować, czytelnik „wprawić musi je w ruch”, odtworzyć sekwencję następujących po sobie zdarzeń. W ten sposób refleksy przybieraja postać synekdochiczno-performatywna. 
Do odmiennej kategorii należy połączenie narracji fabularnych z przedmiotami przedstawionymi, które prowadzi (najczęściej) do powstawania refleksów synekdochiczno-przedmiotowych. Ich oś stanowią wybrane przedmioty, które należą do rozpoznawalnych i dobrze utrwalonych ciagów fabularnych. W przypadku połączenia przedmiotów przedstawionych z narracjami opartymi na akcji dodatkowo (obok refleksów synekdochiczno-przedmiotowych) powstawać moga synekdochiczno-performatywne (co związane jest z koniecznością, wprawienia przedmiotów w ruch”, ponieważ to stanowi warunek ich zrozumienia). Z podobna sytuacją mamy do czynienia w przypadku kontaminacji fabuł i akcji z wyglądami uschematyzowanymi. Także i tutaj mamy do czynienia z powstawaniem refleksów opartych na utrwalonych (schematycznych) wyobrażeniach przedmiotów, które moga być przywoływane w postaci refleksów statycznych.

\section{5.}

Wnioski, wypływające z rozpoznania refleksów czysto intencjonalnych, zmierzają w trzech kierunkach. Po pierwsze, że refleksy są konstrukcjami złożonymi (wieloskładnikowymi), mają charakter subiektywny (ponieważ wytwarzane są w immanencji podmiotu), a ich powstawanie łączy się zawsze z przetworzeniem przedmiotów czysto intencjonalnych. Rytm myśli, który nie jest ograniczony przez konstrukcję dzieła (choć jest przez nią inspirowany), powoduje, że refleksy stają się bytami autonomicznymi, które moga odrywać się od swoich literackich referentów.

Po drugie, że refleksy mają postać nietrwała. Czytelnicy w dowolny sposób - właściwy dla swoich potrzeb - moga przechodzić od jednych refleksów do innych. Mogą także decydować o ich hierarchii. Z tych też powodów trudno byłoby przypisywać im własności podobne do tych, które posiadaja przedmioty czysto intencjonalne. Wydaje się raczej, że refleksy sa ich subiektywnymi emanacjami. Dlatego właśnie żadna ich charakterystyka nie może mieć wymiaru kategorycznego, a podejmowane w tym zakresie próby uświadamiają jedynie, że istnieją ogólne tendencje sprzyjające tworzeniu się refleksów określonego typu.

Po trzecie, refleksy prowokują do wykorzystania także nieliteraturoznawczych narzędzi badawczych - do wykorzystania doświadczeń płynących z neurofizjologii i kognitywistyki. W ten sposób prowokują do ujęć transdyscyplinarnych, akcentujacych znaczenie tego, co znajduje się pomiędzy dyscyplinami i poza nimi, co nie należy do żadnej z nich, ale stanowi obszar graniczny, rozmyty o niejasnej klasyfikacji poznawczej i jednocześnie dużym znaczeniu. Tak rozumiana transdyscyplinarność nie prowadzi do zamazy- 
wania granic między dziedzinami ani do ich łączenia ${ }^{24}$. Raczej do wydobycia sensów ukrytych, trudno-opisywalnych, złożonych.

Możliwości, których transdyscyplinarność dostarcza literaturoznawstwu (ale także innym dziedzinom humanistycznym), nie pozostają w konflikcie z dotychczasowymi ujęciami badawczymi. Poszczególne dyscypliny (nie tracąc własnej tożsamości) nastawione sa na budowanie transpoznawczych, transnarzędziowych i transinterpretacyjnych strategii. Powstaja one z powodów pragmatycznych. Z potrzeby badania obszarów, których nie można oświetlić pojedynczym strumieniem, ponieważ potrzebne jest do tego światło pochodzące z wielu źródeł. To światło może być bardzo pożyteczne w rozpoznawaniu problematyki literaturoznawczo-filozoficznej. Dostarczając nowych impulsów badawczych, pozwala na znaczące poszerzenie poznawczej perspektywy.

\section{BIBLIOGRAFIA}

Annas J., An Introduction to Plato's Republic, Oxford 1981.

Arnheim R., Myślenie wzrokowe, tłum. M. Przylipiak, Gdańsk 2011.

Arystoteles, Poetyka 1450a, 25, tłum. H. Podbielski, BN seria II, nr 209, Wrocław 1983. Austin J.A., Jak działać za pomocq słów, [w:] tegoż, Mówienie i poznawanie, tłum. J. Woleński, Warszawa 1993, s. 550-708.

Axer J., Filolog w teatrze, Warszawa 1991.

Brentano F., Psychologia z empirycznego punktu widzenia, tłum. W. Galewicz, Warszawa 1999.

Chrudzimski A., Intentionalität, Zeitbewusstsein und Intersubjektivität. Studien zur Phänomenologie von Brentano bis Ingarden, Frankfurt 2005.

Chrudzimski Z., Teoria intencjonalności Romana Ingardena, „Edukacja Filozoficzna” 1998, 25, s. 249-262.

Damasio A., Bład Kartezjusza. Emocje, rozum i ludzki mózg, tłum. M. Karpiński, Poznań 2011.

Damasio A., Jak umyst zyskał jaźń. Konstruowanie świadomego mózgu, tłum. N. Radomski, Poznań 2011.

Genette G., Palimsestes. La literature au second degre, Paris 1982.

Heidegger M., Kant a problem metafizyki, tłum. B. Baran, Warszawa 1989.

Hopensztand D., Mowa pozornie zależna w kontekście „Czarnych skrzydet”, [w:] Stylistyka teoretyczna w Polsce, red. K. Budzyk, Warszawa 1946.

Husserl E., Vorlesungen über Bedeutungslehre. Sommersemester 1908, (Husserliana XXVI, hrsg. von U. Panzer), Dordrecht 1986.

Ingarden R., O dziele literackim, Warszawa 1960.

${ }^{24}$ Zob. m.in. H. Novotny, P. Scott, M. Gibbson, Re-Thinking Science: Knowledge and the Public in an Age of Uncertainty, Cambridge 2001. 
Ingarden R., O pytaniach esencjalnych, [w:] tegoż, Z teorii języka i filozoficznych podstaw logiki, Warszawa 1972.

Ingarden R., Studia z estetyki, t. 1, Warszawa 1956.

Ingarden R., Z badań nad filozofia wspótczesna, Warszawa 1963.

Krokos J., Odstanianie intencjonalności, Warszawa 2013, s. 19.

Kristeva J., Semiotique. Recherches pour une semanalise, Paris 1969.

Lem S., Filozofia przypadku. Literatura w świetle empirii, Kraków 1968.

Meinong A., „Über Gegenstandstheorie”, in Gesamtausgabe, Graz 1971, s. 481-535.

Münch D., Intention und Zeichen. Untersuchungen zu Franz Brentano und zu Edmund Husserls Frühwerk, Frankfurt am Main 1993.

Novotny H., Scott P., Gibbson M., Re-Thinking Science: Knowledge and the Public in an Age of Uncertainty, Cambridge 2001.

Sachs-Hombach K., Philosophische Psychologie im 19. Jahrhundert. Ihre Ent-stehung und Problemgeschichte, Freiburg-München,1993.

Rumelhart D.E., The architecture of mind. A connectionist approach, [w:] Foundation of Cognitive Science, red. M.J. Posner, Boston 1993, s. 133-159.

Szczepańska A., Estetyka Romana Ingardena, Warszawa 1989.

Wawrzyniak A., Egzystencja, [w:] Powszechna encyklopedia filozofii, red. A. Maryniarczyk, t. 3, Lublin 2002, s. 33-34.

Wróbel Ł., Intencjonalność i referencja. Ku fenomenologii form gatunkowych. „Teka Komisji Polsko-Ukraińskich Związków Kulturowych”, Lublin 2009, z. 4, s. 44-45. 
